\title{
Modifiable factors of vitamin D status among a Brazilian osteoporotic population attended a public outpatient clinic
}

\author{
Fatores modificáveis do status de vitamina $D$ em uma população \\ brasileira de osteoporóticos assistidos em um ambulatório público
}

Marília Brasilio Rodrigues Camargo', Ilda Sizue Kunii', Lilian Fukusima Hayashi', Patrícia Muszkat', Catherine Gusman Anelli', Rosângela Villa Marin-Mio', Lígia Araújo Martini², Natasha França ${ }^{2}$, Marise Lazaretti-Castro'

' Division of Endocrinology, School of Medicine, Federal University of São Paulo (Unifesp), São Paulo, SP, Brazil ${ }^{2}$ Department of Nutrition, Faculty of Public Health, University of São Paulo (USP), São Paulo, SP, Brazil

Correspondence to:

Marília Brasilio Rodrigues Camargo Av. Nove de Julho, 5581, ap. 30 01407-200 - São Paulo, SP, Brazil lilacamargo@uol.com.br

Received on Apr/2/2014 Accepted on Jun/1/2014

DOI: 10.1590/0004-2730000003393

\begin{abstract}
Objectives: To evaluate the serum 25-hydroxyvitamin D [25(OH)D] concentration in Brazilian osteoporotic patients and the modifiable factors of vitamin D status in this population. Subjects and methods: In a cross-sectional study, 363 community-dwelling patients who sought specialized medical care were evaluated between autumn and spring in São Paulo, Brazil. Serum levels of 25(OH)D and parathormone (PTH), biochemical and anthropometric measurements, and bone density scans were obtained. The group was assessed using two questionnaires: one questionnaire covered lifestyle and dietary habits, skin phototype, sun exposure, medical conditions, and levels of vitamin D supplementation (cholecalciferol); the other questionnaire assessed health-related quality-of-life. Logistic regression and a decision tree were used to assess the association between the variables and the adequacy of vitamin $D$ status. Results: The mean age of the overall sample was $67.9 \pm 8.6$ years, and the mean $25(\mathrm{OH}) \mathrm{D}$ concentration was $24.8 \mathrm{ng} / \mathrm{mL}$. The prevalence of inadequate vitamin D status was high $(73.3 \%)$, although $81.5 \%$ of the subjects were receiving cholecalciferol (mean dose of 8,169 IU/week). 25(OH)D was positively correlated with femoral neck bone mineral density and negatively correlated with PTH. In the multivariate analysis, the dose of cholecalciferol, engagement in physical activity and the month of the year (September) were associated with improvement in vitamin D status. Conclusions: In this osteoporotic population, vitamin $D$ supplementation of $7,000 \mathrm{IU} /$ week is not enough to reach the desired $25(\mathrm{OH})$ $D$ concentration ( $\geq 30 \mathrm{ng} / \mathrm{mL}$ ). Engagement in physical activity and the month of the year are modifiable factors of the vitamin D status in this population. Arq Bras Endocrinol Metab. 2014;58(5):572-82
\end{abstract}

Keywords

25-hydroxyvitamin D; cholecalciferol; physical activity; osteoporosis; Brazil

\section{RESUMO}

Objetivos: Avaliar a concentração sérica de 25-hidroxivitamina D [25(OH)D] em pacientes osteoporóticos brasileiros e os fatores modificáveis do status de vitamina D nesta população. Sujeitos e métodos: Em um estudo transversal, 363 pacientes, residentes na comunidade, que procuravam atendimento médico especializado, foram avaliados entre o outono e a primavera, em São Paulo, Brasil. Níveis séricos de $25(\mathrm{OH}) \mathrm{D}$ e paratormônio (PTH), avaliações bioquímicas e antropométricas e exames de densitometria óssea foram obtidos. 0 grupo foi avaliado por meio de dois questionários: um questionário abordou estilo de vida e hábitos alimentares, fototipo de pele, exposição solar, problemas médicos e os níveis de suplementação de vitamina $D$ (colecalciferol); o outro questionário avaliou a qualidade de vida relacionada à saúde. Regressão logística e árvore de decisão foram utilizadas para avaliar a associação entre as variáveis e a adequação do status de vitamina D. Resultados: A idade média da amostra foi de $67,9 \pm 8,6$ anos e a concentração média de $25(\mathrm{OH}) \mathrm{D}$ foi de $24,8 \mathrm{ng} / \mathrm{mL}$. A prevalência de um status de vitamina $D$ inadequado foi elevada $(73,3 \%$ ), apesar de $81,5 \%$ dos indivíduos receberem colecalciferol (dose média de 8.169 UI/semana). 25(OH)D correlacionou-se positivamente com a densidade mineral óssea do colo de fêmur e negativamente com PTH. Nas análises multivariadas, a dose de colecalciferol, a prática de exercícios físicos e o mês do ano (setembro) foram associados com a melhora do status de vitamina D. Conclusões: Nesta população osteoporótica, a suplementação de $7.000 \mathrm{UI} /$ semana não é suficiente para atingir a concentração desejada de $25(\mathrm{OH}) \mathrm{D}(\geq 30 \mathrm{ng} / \mathrm{mL})$. A prática de exercícios físicos e o mês do ano são fatores modificáveis do status de vitamina $D$ na população estudada. Arq Bras Endocrinol Metab. 2014;58(5):572-82

Descritores

25-hidroxivitamina D; colecalciferol; atividade física; osteoporose; Brasil 


\section{INTRODUCTION}

$\mathrm{T}$ he central role of vitamin $\mathrm{D}$ in bone health and muscle function has long been acknowledged, and evidence suggests that adequate vitamin D status is essential for the management of osteoporosis (1-4). Controversy exists regarding the optimum level of serum 25-hydroxyvitamin D [25(OH)D] in a healthy population. However, most experts agree that a serum $25(\mathrm{OH}) \mathrm{D}$ concentration of at least 30 $\mathrm{ng} / \mathrm{mL}$ is the endpoint for skeletal health outcomes $(1,2,5)$. Inadequate vitamin D status induces secondary hyperparathyroidism, which stimulates bone loss and subsequently increases the risk of osteoporosis and fractures (6). Exposure to sunlight, which induces vitamin D synthesis in the skin, is an important determinant of vitamin D status, and several studies have shown that its production is influenced by a variety of factors, including skin pigmentation, clothing style, season and air pollution, among others (7-10). Serum $25(\mathrm{OH}) \mathrm{D}$ concentration decreases with increasing age and body mass index (BMI) and increases with increasing intake of vitamin $\mathrm{D}$ and physical activity $(5,8,9)$.

In Brazil, a country with a sunny climate, a proper amount of $25(\mathrm{OH}) \mathrm{D}$ in the population would be expected. However, a survey among Brazilian adults revealed high prevalence rates of hypovitaminosis $\mathrm{D}$ in the winter and in the summer $(77 \%$ and $37 \%$, respectively) (5). Similarly, an $86 \%$ prevalence rate of inadequate vitamin D status was reported in Brazilian postmenopausal women receiving vitamin $\mathrm{D}$ supplementation of 400 IU/day (11). By contrast, a lower prevalence of hypovitaminosis $\mathrm{D}$ was observed in elderly Brazilian practitioners of outdoor physical activities (7\% in the summer and $19 \%$ in the winter) (9).

Because inadequate vitamin D status is a health problem worldwide, identifying modifiable factors of vitamin $\mathrm{D}$ status has clinical relevance $(10,12)$. The aims of our study were, firstly, to evaluate the $25(\mathrm{OH})$ $\mathrm{D}$ concentration and the prevalence of hypovitaminosis $\mathrm{D}$ in Brazilian osteoporotic patients who were seeking specialized medical care. Secondly, we examined the clinical and nutritional profile of these patients and potential modifiable factors of vitamin D status, including levels of vitamin D supplementation and lifestyle habits. Thirdly, we attempted to identify whether vitamin D status influences muscle strength and functional ability in these patients.

\section{SUBJECTS AND METHODS}

This cross-sectional study evaluated 363 community-dwelling patients who attended a specialized outpatient clinic of the Federal University of São Paulo. Postmenopausal women over the age of 45 (absence of menses for a minimum of 2 years) and men older than 50 who were undergoing osteoporosis treatment for at least 3 months were eligible to participate. Osteoporosis was defined as a bone mineral density (BMD) T-score at the distal radius, femoral neck, total hip and/ or lumbar spine $\leq-2.5 \mathrm{SD}$, as well as a BMD T-score between -1.0 and $-2.5 \mathrm{SD}$ at any of these sites, in addition to a history of low-trauma, fragility fractures of the hip, spine or wrist after the age of $45(13,14)$. Enrollment occurred between late autumn and late spring in 2009, 2010 and 2011. All of the subjects formerly received or were receiving treatment for osteoporosis with any approved osteoporosis medication, including calcium and vitamin D supplementation.

The study protocol was approved by the University Research Ethics Committee, and written consent was obtained from all of the participants.

Fasting samples of blood and urine were obtained from the patients, and the samples were kept frozen at $-20^{\circ} \mathrm{C}$ until the analyses were performed. Height and weight were recorded. A trained physician assessed the group using a standard questionnaire and a health-related quality-of-life questionnaire (the Health Assessment Questionnaire Disability Index - HAQ-DI) (15). Bone density and body composition were assessed using dual-energy X-ray absorptiometry (DXA). Muscle strength tests were performed to measure hand-grip strength, hip flexor strength and knee extensor strength.

\section{Laboratory measurements}

Serum total calcium $(\mathrm{Ca})$, phosphorus $(\mathrm{P})$, albumin (Alb) and urine calcium (UCa) were measured using the colorimetric method; Ca was adjusted for Alb concentration (16). Urine creatinine (UCr) and serum creatinine were measured using the kinetic colorimetric method. Creatinine clearance $(\mathrm{ClCr})$ was calculated using the Cockcroft-Gault equation. The UCa-UCr ratio was calculated. Aspartate aminotransferase (AST), alanine aminotransferase (ALT) and alkaline phosphatase (ALP) were measured using an enzymatic method. C-terminal telopeptide of collagen type I (CTX-I) and total procollagen type 1 amino-terminal propeptide (PINP) as well as parathormone (PTH) were measu- 
red using commercial kits (chemoluminescence, Roche, Elecsys 2010 analyzer, USA). For CTX-I, the intra-assay and inter-assay coefficients of variation (CVs) were $4.6 \%$ and $4.7 \%$, respectively; for PINP, the intra-assay and inter-assay CVs were $1.8 \%$ and $2.7 \%$, respectively; and for $\mathrm{PTH}$, the intra-assay and inter-assay CVs were $3.0 \%$ and $3.5 \%$, respectively. Total $25(\mathrm{OH}) \mathrm{D}$ was evaluated using a commercial chemiluminescent immunoassay method (DiaSorin, Liaison analyzer, USA) with intra-assay and inter-assay CVs of $1.6 \%$ and $5.6 \%$, respectively.

\section{Anthropometrics}

Weight and height were measured using a digital scale and a wall-mounted stadiometer, respectively. BMI was calculated and categorized according to the World Health Organization classification (17).

\section{Standard questionnaire}

The participants were asked about their age, age of menopause, place of residence, level of education, and the following factors (highlighted in italics):

Fractures that occurred after falls after the age of 45 and in the past 5 years, as well as the fracture sites, were recorded.

The subjects were categorized into those who engaged in some form of regular physical exercise (any regular exercise for a minimum of 30 minutes per time) and those who did not. The amount of exercise per week was categorized as 1 or 2 times, $3-5$ times or $\geq 6$ times.

Smoking: the subjects were classified as smokers or non-smokers; the non-smoking group comprised people who said they had never smoked or had smoked at some stage in their lives.

Medical conditions related to low bone mass and vitamin D inadequacy were recorded.

The use of concurrent medications within the last 3 months was recorded, including any bone-related therapy, such as bisphosphonates, raloxifene, teriparatide and hormone replacement therapy, and medications that could potentially affect bone mineral metabolism, such as glucocorticoids and anticonvulsants. The use of calcium and vitamin D supplements was also recorded.

The participants were categorized according to their skin phototype (Fitzpatrick classification). Non-black skin types are classified as "I" to "IV", and black skin types are classified as "V" and "VI" $(18,19)$.

Use of sunscreen: the subjects were classified as usual users or non-users of sunscreen according to their own evaluation.
Sun exposure was measured with the sun index (SI). The SI corresponds to the number of hours per week spent outside without sun protection multiplied by the percentage of the body exposed to sunlight ( $9 \%$ for face, $1 \%$ for each hand, $9 \%$ for each arm and $18 \%$ for each leg) (13).

Calcium and vitamin $D$ intake were assessed by analyzing the patients' dietary records. The participants were oriented to register their food intake for a period of 3 alternate days, including 2 weekdays and 1 weekend day. Initially, the intake amounts were measured using homemade measures, and these values were later converted into kilograms and into macronutrient and micronutrient amounts. The data were analyzed using the Nutrition Data System for Research software (version 2007; NDS-R, University of Minnesota, Minneapolis, MN, USA).

\section{HAQ-DI}

The HAQ-DI consists of 20 questions that cover activities of daily life, such as dressing, rising, eating, walking, performing hygiene activities, reaching, gripping, and performing ordinary activities. According to the answers, the patients were classified as having mild to moderate difficulty, moderate to severe disability or severe to very severe disability $(15,20)$.

\section{Muscle strength tests}

Blood pressure and the skin condition of the lower limbs were verified before beginning the tests, which were not performed on patients with high blood pressure (systolic $\geq 170 \mathrm{mmHg}$ and/or diastolic $\geq 100 \mathrm{mmHg}$ ), pain, limb immobilization, varicose veins or paresis or on patients who refused. The grip strength of both the right and left hands was measured using a hand-grip dynamometer (Analogue Dial - A5001, Takei, Japan). The maximum isometric strength of the hip flexor and knee extensor on the subjects' dominant limb was tested using a portable mechanical dynamometer (model 01163; Manual Lafayette Muscle Test System, USA) as described elsewhere (21).

\section{DXA measurements}

The lumbar spine (LS) at Ll-L4, total femur (TF), femoral neck (FN) and body composition (total fat and lean body mass and total body BMD) were measured using DXA (Discovery A, QDR for Windows XP, Hologic, USA). BMD was assessed and analyzed according to the recommendations of the Brazilian Society 
for Clinical Densitometry (14). The whole body DXA exams were conducted in accordance with the procedures recommended by the manufacturer (Hologic, Inc., Bedford, MA) (22). The CV was $0.8 \%$ for the LS and the TF and $1.2 \%$ for the FN. The variability (CV) for total fat and lean body mass and total body BMD from Hologic QDR DXA instruments ranges from 1.2-3.2\%, $0.6-2.2 \%$ and $1.0-1.8 \%$, respectively $(23,24)$.

\section{Statistical analysis}

For all of the statistical analysis, we used the SPSS, version 17.0 (USA). The numerical variables were described with medians, means and standard deviations (SDs), and the categorical variables were described with absolute and relative frequencies. The associations between the categorical variables were verified using the chi-square test or Fisher's exact test, as appropriate. The quantitative variables of 2 groups were compared using Student's t-test or the Mann-Whitney test, as appropriate. For comparing more than 2 groups, the Kruskal-Wallis nonparametric test was used. After the differences between the groups were detected, subsequent Mann-Whitney tests were conducted to locate the differences; the Bonferroni correction was applied to maintain the level of global significance. Subsequently, we used Pearson's linear correlation to establish the association between $25(\mathrm{OH}) \mathrm{D}$ and the quantitative variables. The partial correlation was used to assess the associations between 25(OH)D and the FN T-score, the FN BMD and the total body BMD after controlling for the physical activity variable. Odds ratios (OR, with 95\% CI) were determined using binary logistic regression (backward method). A decision tree was also produced as a form of multivariate analysis: the algorithm employed was Chi-square Automatic Interaction Detection.

There were no significant differences between the sexes in 25(OH)D concentration, age, BMI, lifestyle and dietary habits, skin phototype or sun exposure. Thus, both sexes were considered together in the analyses of the associations between $25(\mathrm{OH}) \mathrm{D}$ and the quantitative variables as well as in the multivariate analyses.

For all of the statistical tests, the results were considered significant when $\mathrm{p}<0.05$.

\section{RESULTS}

Figure 1 shows the prevalence of inadequate vitamin $\mathrm{D}$ status according to various cut-off points for the $25(\mathrm{OH}) \mathrm{D}$ concentration.

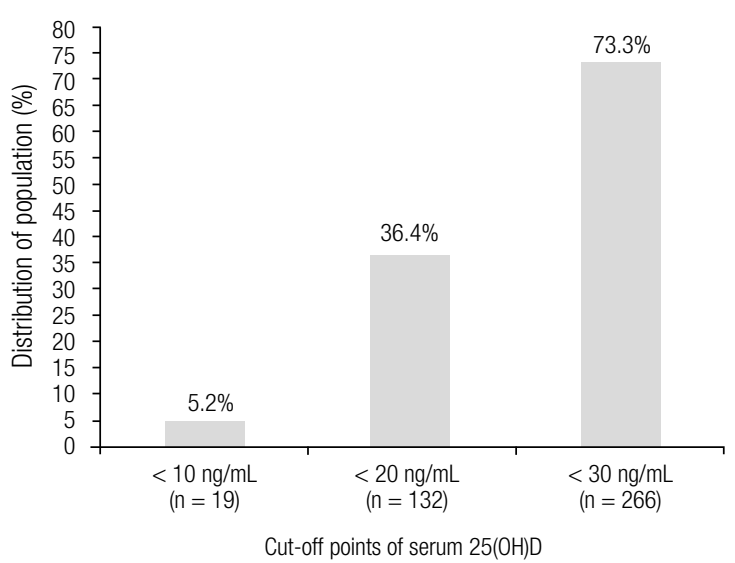

Figure 1. Vitamin D status: distribution of the population, according to the cut-off points for serum 25(OH)D levels.

The sample comprised primarily of women $(\mathrm{n}=$ $343 ; 94.5 \%$ ). The metropolitan area of São Paulo (n $=353 ; 97.2 \%)$ was the main place of residence reported. Overall, $13.5 \%$ of the participants $(n=49)$ met the criteria for obesity $\left(B M I \geq 30 \mathrm{~kg} / \mathrm{m}^{2}\right)$. The mean age of menopause was $45.9 \pm 6.1$ years, and the mean time between menopause and the study was 21.8 years (range $2.0-48.0$ years).

The food records were completed by $45 \%$ of the participants (154 women and 9 men). Excluding supplemental intake, the average daily calcium consumption was $808 \pm 362 \mathrm{mg}$, and the average daily vitamin D intake was $173 \pm 92$ IU. The median intake of dietary calcium was $751 \mathrm{mg} /$ day in women and $595 \mathrm{mg} /$ day in men, and the median intake of dietary vitamin D was $155 \mathrm{IU} /$ day in women and $112 \mathrm{IU} /$ day in men. There was no significant difference between the genders in the energy consumed ( $\mathrm{kcal} /$ day) or in the daily consumption of calcium or vitamin D (Mann-Whitney, $\mathrm{p}=0.320, \mathrm{p}=0.561$, and $\mathrm{p}=0.495$, respectively).

Table 1 shows the summary measures of age, BMI, laboratory evaluations, supplemental dose of calcium/ vitamin D and DXA results of the study population as a whole and according to gender.

In table 2, the characteristics of the population are shown.

Seventy-four patients $(20.4 \%)$ reported experiencing one or more clinical fractures of the wrist, hip and/or spine after the age of 45 . Fifty-seven patients $(15.7 \%)$ reported one $(n=45)$ or more fractures $(n=$ 12) related to a fall within the past 5 years. The most common fracture site related to a fall was the wrist $(\mathrm{n}=$ 18), followed by the foot $(\mathrm{n}=9)$, the hip $(\mathrm{n}=7)$ and the ankle $(\mathrm{n}=5)$. 
Table 1. Clinical and laboratory parameters of the study population

\begin{tabular}{|c|c|c|c|c|c|c|c|c|c|c|c|c|c|}
\hline \multirow{2}{*}{ Variable } & \multicolumn{4}{|c|}{ Whole group } & \multicolumn{4}{|c|}{ Female } & \multicolumn{4}{|c|}{ Male } & \multirow{2}{*}{$\begin{array}{c}\begin{array}{c}\text { Comparison } \\
\text { Between } \\
\text { Sexes }\end{array} \\
\text { p value }\end{array}$} \\
\hline & $\mathbf{n}$ & Median & Minimum & Maximum & $\mathbf{n}$ & Median & Minimum & Maximum & $\mathbf{n}$ & Median & Minimum & Maximum & \\
\hline Age, years & 363 & 68.0 & 47.0 & 87.0 & 343 & 68.0 & 47.0 & 87.0 & 20 & 68.0 & 54.0 & 84.0 & $0.922^{*}$ \\
\hline $\mathrm{BMl}, \mathrm{kg} / \mathrm{m}^{2}$ & 363 & 25.6 & 16.6 & 42.8 & 343 & 25.6 & 16.6 & 42.8 & 20 & 26.8 & 19.3 & 36.4 & 0.208 \\
\hline $25(\mathrm{OH}) \mathrm{D}, \mathrm{ng} / \mathrm{mL}_{(1)}$ & 363 & 23.1 & 6.4 & 94.6 & 343 & 23.0 & 6.4 & 94.6 & 20 & 25.9 & 10.9 & 46.7 & 0.486 \\
\hline PTH, pg/mL & 363 & 52.4 & 12.4 & 176.8 & 343 & 52.2 & 12.4 & 176.8 & 20 & 52.8 & 28.7 & 133.0 & 0.588 \\
\hline PINP, ng/mL & 363 & 22.5 & 5.0 & 180.4 & 343 & 22.5 & 5.0 & 180.4 & 20 & 15.3 & 6.5 & 171.9 & 0.234 \\
\hline CTX-I, ng/mL & 363 & 0.147 & 0.010 & 1.270 & 343 & 0.148 & 0.010 & 1.270 & 20 & 0.113 & 0.010 & 0.583 & 0.354 \\
\hline Alb, $g / d_{(5)}$ & 363 & 4.3 & 3.1 & 5.0 & 343 & 4.3 & 3.1 & 5.0 & 20 & 4.3 & 3.6 & 4.8 & 0.270 \\
\hline $\mathrm{ClCr}, \mathrm{mL} / \mathrm{min}_{(6)}$ & 363 & 66 & 26 & 153 & 343 & 66.0 & 26 & 153 & 20 & 67.0 & 46.0 & 121.0 & 0.526 \\
\hline $\mathrm{Ca}, \mathrm{mg} / \mathrm{dL}_{(7)}$ & 363 & 9.3 & 8.0 & 10.7 & 343 & 9.3 & 8.0 & 10.7 & 20 & 9.1 & 8.6 & 10.3 & 0.425 \\
\hline $\mathrm{P}, \mathrm{mg} / \mathrm{dL}_{(8)}$ & 363 & 3.5 & 1.9 & 4.8 & 343 & 3.5 & 2.0 & 4.8 & 20 & 3.2 & 1.9 & 3.8 & $<0.001$ \\
\hline $\mathrm{AST}, \mathrm{U} / \mathrm{L}_{(9)}$ & 363 & 20.0 & 11 & 55 & 343 & 20.0 & 11.0 & 55.0 & 20 & 21.0 & 15.0 & 31.0 & 0.652 \\
\hline$A L T, U / L_{(10)}$ & 363 & 13.0 & 4 & 54 & 343 & 13.0 & 4 & 54 & 20 & 16.0 & 8.0 & 46.0 & 0.041 \\
\hline$A L P, U / L_{(11)}$ & 363 & 62.0 & 19 & 420 & 343 & 62.0 & 19 & 420 & 20 & 54.3 & 32.0 & 84.0 & 0.092 \\
\hline $\mathrm{UCa} / \mathrm{UCr}_{(12)}$ & 362 & 0.079 & 0.002 & 0.481 & 342 & 0.079 & 0.003 & 0.481 & 20 & 0.068 & 0.002 & 0.194 & 0.551 \\
\hline Cholecalciferol, IU/week & 296 & 7,000 & 400 & 83,333 & 281 & 7,000 & 400 & 83,333 & 15 & 7,000 & 5,000 & 21,000 & 1.000 \\
\hline Calcium suppl., mg/day & 202 & 500 & 178 & 1500 & 189 & 500 & 178 & 1500 & 13 & 500 & 500 & 1000 & 0.261 \\
\hline T-score LS & 344 & -2.8 & -6.1 & 1.2 & 325 & -2.8 & -6.1 & 0.6 & 19 & -2.4 & -5.7 & 1,2 & 0.237 \\
\hline T-score FN & 347 & -1.8 & -4.0 & 1.2 & 329 & -1.8 & -4.0 & 1.2 & 18 & -2.0 & -3.0 & -0.8 & 0.937 \\
\hline T-score TH & 347 & -1.6 & -4.9 & 0.7 & 329 & -1.6 & -4.9 & 0.7 & 18 & -1.5 & -2.7 & -0.2 & 0.565 \\
\hline Total body BMD, g/cm² & 332 & 0.933 & 0.691 & 1.352 & 314 & 0.928 & 0.691 & 1.352 & 18 & 1.024 & 0.891 & 1.227 & $<0.001$ \\
\hline Fat mass, $\%$ & 332 & 35.4 & 15.8 & 49.0 & 314 & 35.7 & 15.8 & 49.0 & 18 & 25.0 & 17.8 & 33.7 & $<0.001$ \\
\hline Lean mass, g & 332 & 37,010 & 24,441 & 67,018 & 314 & 36,402 & 24,441 & 47,929 & 18 & 49,733 & 39,083 & 67,018 & $<0.001$ \\
\hline
\end{tabular}

The nonparametric Mann-Whitney test was used to compare data between the groups, except for the comparison of age (*Student's t-test).

Reference values: (1) 30-100 ng/mL; (2) 15-65 pg/mL; (3) female median $37.09 \mathrm{ng} / \mathrm{mL}$ (5-95 th percentile, 16.27-73.87 ng/mL); (4) female, post menopause, $0.556 \pm 0.226 \mathrm{ng} / \mathrm{mL}$; male, $50-70$ yr, $0.304 \pm 0.200 \mathrm{ng} / \mathrm{mL} ;$ male > $70 \mathrm{yr}, 0.394 \pm 0,230 \mathrm{ng} / \mathrm{mL}$ (5) 3.2-5.6 g/dL; (6) $\geq 60 \mathrm{~mL} / \mathrm{min} ;$ (7) $8.5-10.5 \mathrm{mg} / \mathrm{dL} ;$ (8) $2.5-4.5 \mathrm{mg} / \mathrm{dL} ;$ (9) up to $32 \mathrm{U} / \mathrm{L} ;$ (10) up to $31 \mathrm{U} / \mathrm{L} ;$ (11) $50-250 \mathrm{U} / \mathrm{L} ;(12)$ $<0.210$.

Diabetes and hypertension were reported by $16.8 \%$ and $57.3 \%$ of participants, respectively. Thirty-nine participants (10.7\%) had chronic lung diseases such as asthma and chronic obstructive pulmonary disease. Fifty participants (13.8\%) reported at least one medical condition known to affect the adequacy of vitamin D status, such as chronic liver disease $(\mathrm{n}=10)$, intestinal malabsorption $(\mathrm{n}=7)$, gastric surgery $(\mathrm{n}=$ $3)$, the use of anticonvulsants $(n=4)$, the use of glucocorticoids $(\mathrm{n}=18)$, primary hyperparathyroidism $(\mathrm{n}=6)$, or more than 2 of these medical conditions $(\mathrm{n}=2)$.

The majority of the participants $(81.5 \%)$ were receiving vitamin D supplementation (cholecalciferol) as well as bisphosphonate treatment (75.5\%). Twenty-six participants $(7.2 \%)$ were receiving treatment with raloxifene or hormone replacement therapy, and 3 participants $(0.8 \%)$ were receiving treatment with te- riparatide. In the overall sample $(\mathrm{n}=363)$, the mean cholecalciferol dose was 8,169 IU/week. Considering only the participants using cholecalciferol $(\mathrm{n}=296)$, the mean dose varied according to vitamin $\mathrm{D}$ status: for a $25(\mathrm{OH}) \mathrm{D}$ concentration $<20.0 \mathrm{ng} / \mathrm{mL}(\mathrm{n}=94)$, the mean dose was $8,723 \pm 4,586 \mathrm{IU} /$ week; and for a $25(\mathrm{OH}) \mathrm{D}$ concentration from 20.0 to $29.9 \mathrm{ng} / \mathrm{mL}$ $(\mathrm{n}=112)$, the mean dose was $8,560 \pm 3,830 \mathrm{IU} /$ week. The cholecalciferol dose was significantly higher only for the patients with $25(\mathrm{OH}) \mathrm{D} \geq 30.0 \mathrm{ng} / \mathrm{mL}$ $(\mathrm{n}=90)$, namely, 13,185 $\pm 12,618 \mathrm{IU} /$ week (Kruskal-Wallis, $\mathrm{p}<0.001)$. There was no relationship between vitamin $\mathrm{D}$ status and the presence or absence of diseases such as diabetes $\left(\chi^{2}=1.49, \mathrm{p}=0.475\right)$, hypertension $\left(\chi^{2}=0.35, \mathrm{p}=0.840\right)$ and chronic lung disease $\left(\chi^{2}=\right.$ 1.67, $\mathrm{p}=0.435)$.

The mean $25(\mathrm{OH}) \mathrm{D}$ concentrations did not differ among the groups according to sex, age $(<60$ years 
Table 2. General characteristics of the study population

\begin{tabular}{|c|c|c|}
\hline \multirow{2}{*}{ Characteristics } & \multicolumn{2}{|c|}{ Whole Group } \\
\hline & $\mathbf{n}$ & $\%$ \\
\hline Highest level of education & 363 & 100.0 \\
\hline Illiteracy/reading and writing & 44 & 12.1 \\
\hline Up to elementary school & 239 & 65.8 \\
\hline Up to high school & 55 & 15.2 \\
\hline Up to university & 25 & 6.9 \\
\hline Sunscreen use & 363 & 100.0 \\
\hline Yes & 130 & 35.8 \\
\hline No & 233 & 64.2 \\
\hline Skin phototype & 363 & 100.0 \\
\hline Type I & 7 & 1.9 \\
\hline Type ॥ & 79 & 21.8 \\
\hline Type III & 174 & 47.9 \\
\hline Type IV & 87 & 24.0 \\
\hline Type $V$ and $V I$ & 16 & 4.4 \\
\hline BMI $\left(\mathbf{k g} / \mathbf{m}^{2}\right)$ & 363 & 100.0 \\
\hline$<18.5$ & 9 & 2.5 \\
\hline $18.5-24.9$ & 156 & 43.0 \\
\hline $25.0-29.9$ & 149 & 41.0 \\
\hline$\geq 30.0$ & 49 & 13.5 \\
\hline HAQ-DI & 362 & 100.0 \\
\hline Mild to moderate difficulty & 283 & 78.2 \\
\hline Moderate to severe disability & 67 & 18.5 \\
\hline Severe to very severe disability & 12 & 3.3 \\
\hline Sun exposure index (\#) & 363 & 100.0 \\
\hline$\leq 2.03$ & 285 & 78.5 \\
\hline$>2.03$ & 78 & 21.5 \\
\hline
\end{tabular}

\# SI of 2.03, for example, corresponds to having one's face, arms and hands exposed to the sun without protection for $7 \mathrm{~h}$ a week.

old, 61-70 years old and > 70 years old), BMI, skin phototype, HAQ-DI score, SI $(\leq 2.03$ and $>2.03)$, use of sunscreen (yes/no), history of medical conditions known to affect the adequacy of vitamin D status (yes/no) and history of fractures (yes/no). The serum $25(\mathrm{OH})$ D concentration was also compared across SI quartiles, and no difference was observed (Kruskal-Wallis, $\mathrm{p}=0.916)$. Table 3 shows the factors associated with higher $25(\mathrm{OH}) \mathrm{D}$ concentrations: engagement in physical activity, vitamin D supplementation, not-smoking, and a PTH concentration in the normal range. As expected, the participants who had their blood drawn in August had lower 25(OH)D concentrations compared with the June and September groups.
The serum 25(OH)D concentration had weak but significant correlations with the cholecalciferol dose $(\mathrm{r}=0.272, \mathrm{p}<0.001)$, the FN T-score $(\mathrm{r}=0.141, \mathrm{p}$ $=0.009), \mathrm{FN}$ BMD $(\mathrm{r}=0.138, \mathrm{p}=0.010)$ and total body BMD $(\mathrm{r}=0.141, \mathrm{p}=0.010)$ and a negative correlation with PTH $(\mathrm{r}=-0.138, \mathrm{p}=0.009)$. Even after controlling for physical activity, serum $25(\mathrm{OH}) \mathrm{D}$ still maintained positive correlations with the FN T-score $(\mathrm{r}$ $=0.148, \mathrm{p}=0.007), \mathrm{FN}$ BMD $(\mathrm{r}=0.145, \mathrm{p}=0.008)$ and total body BMD $(\mathrm{r}=0.145, \mathrm{p}=0.008)$. The correlations between $25(\mathrm{OH}) \mathrm{D}$ and the muscle strength tests were not statistically significant.

In the multivariate analysis, we assessed the effects of various factors on the adequacy of the $25(\mathrm{OH}) \mathrm{D}$ concentration $(\geq 30 \mathrm{ng} / \mathrm{mL}$ ) by using logistic regression. The response variable was the adequacy of vitamin $\mathrm{D}$ status. The explanatory variables we tested were age, $\mathrm{ClCr}$, BMI, skin phototype, SI, fat mass, the cholecalciferol dose, the month of the blood draw and physical activity. Only the cholecalciferol dose, physical exercise and the month of the blood draw were significantly associated with the adequacy of vitamin D status. According to the final model, those who engaged in physical activity were 2.12 times more likely to have a serum $25(\mathrm{OH}) \mathrm{D}$ concentration $\geq 30 \mathrm{ng} /$ $\mathrm{mL}$ compared with those who did not; those who had their blood drawn in September were 2.52 times more likely to have a serum $25(\mathrm{OH}) \mathrm{D}$ concentration $\geq 30$ $\mathrm{ng} / \mathrm{mL}$ than those who did not. Furthermore, the final model showed that the chance of having adequate vitamin D status increased by $12 \%$ for each 1,000 $\mathrm{IU} /$ week increase in the dosage of cholecalciferol. To better understand the relationship between the above mentioned explanatory variables and the concentration of $25(\mathrm{OH}) \mathrm{D}$, we used the decision tree method (Figure 2). We could confirm the association between the cholecalciferol dose and physical activity and higher $25(\mathrm{OH}) \mathrm{D}$ concentrations. The patients who were taking a cholecalciferol dose $\leq 6,986 \mathrm{IU} /$ week had a mean $25(\mathrm{OH}) \mathrm{D}$ concentration of $20.2 \mathrm{ng} / \mathrm{mL}$. Physical activity was associated with improvement when the patient had a suboptimal $25(\mathrm{OH}) \mathrm{D}$ mean value (Node 2, Figure 2). Node 3 (Figure 2) indicated that 29 patients were taking a cholecalciferol dose > $14,000 \mathrm{IU} /$ week; in this group, the mean $25(\mathrm{OH})$ D concentration was $32.7 \mathrm{ng} / \mathrm{mL}$. The participants who did not engage in physical activity did not differ significantly from those who were physically active in terms of age, sex, BMI, functional abilities, comorbid conditions or treatment. 
Table 3. Factors related to higher levels of $25(\mathrm{OH}) \mathrm{D}$ in the study population

\begin{tabular}{|c|c|c|c|c|}
\hline \multirow{2}{*}{ Variable } & \multirow{2}{*}{ Test } & \multicolumn{3}{|c|}{ 25(OH)D } \\
\hline & & $\mathbf{p}$ & Mean \pm SD & $\mathbf{n}$ \\
\hline Physical activity & Student's t & 0.033 & $24.8 \pm 11.3$ & 363 \\
\hline Yes & $t=2.15$ & & (B) $26.3 \pm 10.1$ & 155 \\
\hline No & & & (A) $23.7 \pm 11.9$ & 208 \\
\hline Frequency of physical activity & Kruskal-Wallis & 0.007 & $24.8 \pm 11.3$ & 363 \\
\hline No & & & (A) $23.7 \pm 11.9$ & 208 \\
\hline $1-2$ times & & & (B) $27.9 \pm 10.4$ & 62 \\
\hline $3-5$ times & & & $25.3 \pm 9.7$ & 66 \\
\hline More than 6 times & & & $25.0 \pm 10.3$ & 27 \\
\hline Vitamin D supplementation & Student's t & $<0.001$ & $24.8 \pm 11.3$ & 363 \\
\hline Yes & $t=3.88$ & & (B) $25.9 \pm 11.2$ & 296 \\
\hline No & & & (A) $20.1 \pm 10.5$ & 67 \\
\hline Smoking & Student's t & 0.042 & $24.8 \pm 11.3$ & 363 \\
\hline Yes & $t=2.04$ & & (A) $21.4 \pm 7.9$ & 40 \\
\hline No & & & (B) $25.2 \pm 11.6$ & 323 \\
\hline Month of the blood draw & Kruskal-Wallis & 0.026 & $24.8 \pm 11.3$ & 363 \\
\hline June & & & (B) $27.0 \pm 12.6$ & 78 \\
\hline July & & & $24.2 \pm 11.1$ & 61 \\
\hline August & & & (A) $22.8 \pm 9.4$ & 140 \\
\hline September & & & (B) $28.3 \pm 12.7$ & 49 \\
\hline October/November/December & & & $24.4 \pm 11.9$ & 35 \\
\hline PTH & Student's t & \#0.022 & $24.8 \pm 11.3$ & 363 \\
\hline$<15 \mathrm{pg} / \mathrm{mL}$ & $t=2.31$ & & $32.4 \pm-$ & 1 \\
\hline $15-65 \mathrm{pg} / \mathrm{mL}$ & & & (B) $25.6 \pm 11.3$ & 263 \\
\hline$>65 \mathrm{pg} / \mathrm{mL}$ & & & (A) $22.6 \pm 10.9$ & 99 \\
\hline
\end{tabular}

(A) and (B) means are different at the 5\% level of significance. \# Comparison between the groups "PTH 15-65" and "PTH > 65".

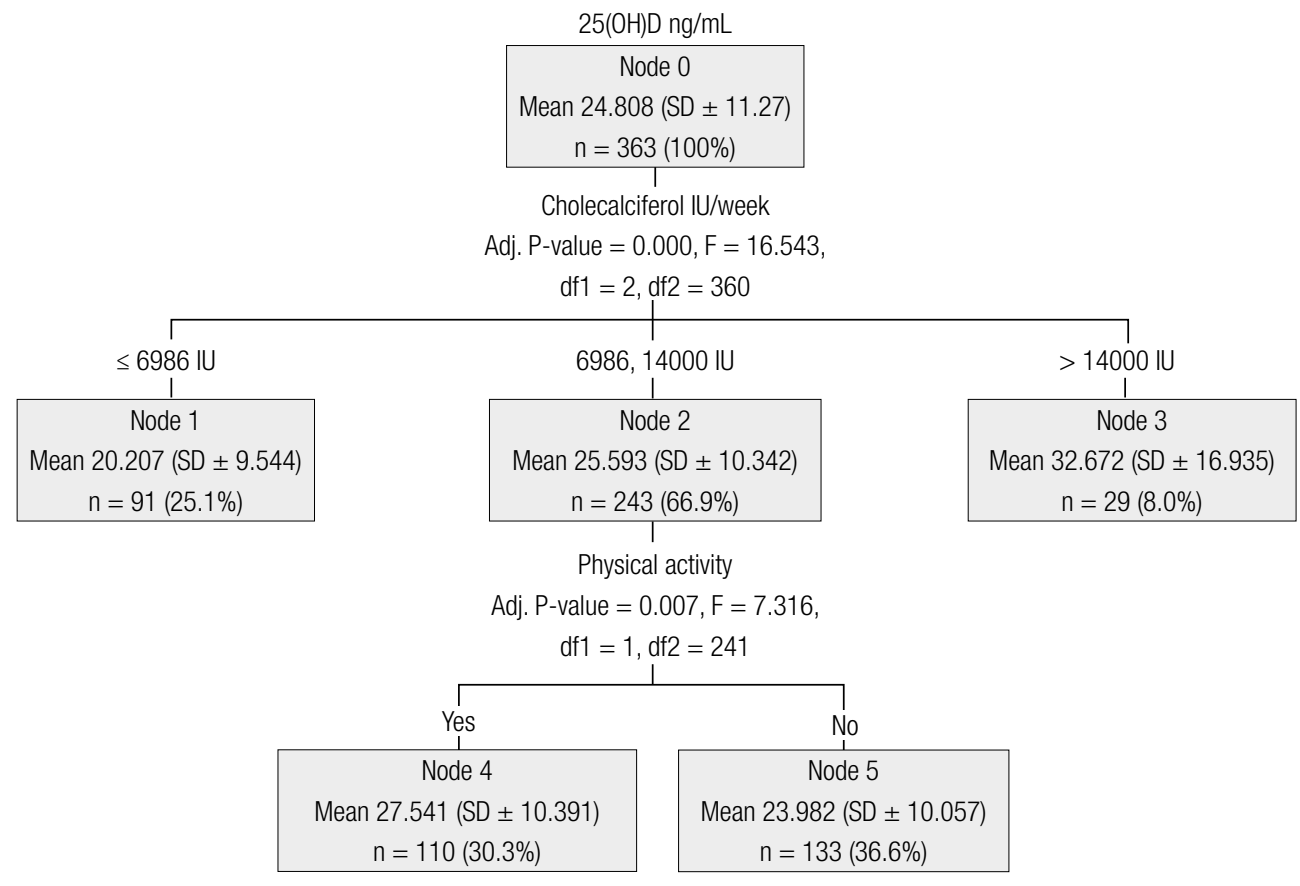

Figure 2. Decision tree: modifiable factors of vitamin D status in the study population. 


\section{DISCUSSION}

Our research covered osteoporotic patients who were seeking secondary care in a public health-care setting. The participants had characteristics similar to the general population of the São Paulo metropolitan area (SPMA) (25-29). The SPMA is located at $23^{\circ} \mathrm{S}$ and $46^{\circ} \mathrm{W}$ in southeastern Brazil with a population over 19 million; $11.3 \%$ of the people are over $60(30)$. The region has approximately 2,000 industries with high pollution potential and a fleet of more than 8.4 million vehicles $(30)$. A low level of $25(\mathrm{OH}) \mathrm{D}$ is highly prevalent in the Brazilian population in various regions of the country $(31,32)$, even in areas closer to the equator (33). However, the high prevalence of inadequate vitamin $\mathrm{D}$ status in our sample $-36 \%$ had vitamin $\mathrm{D}$ status $<20 \mathrm{ng} / \mathrm{mL}$, and $73 \%$ had vitamin $\mathrm{D}$ status $<$ $30 \mathrm{ng} / \mathrm{mL}$ - was unexpected, considering that $81.5 \%$ of the subjects were receiving supplemental vitamin D (the mean cholecalciferol dose was 8,169 IU/week). "The Brazilian Osteoporosis Study" (BRAZOS) revealed low dietary intake of vitamin D (80 IU/day) and calcium ( 400 mg/day) in southeastern Brazil (34). Although their intake was still inadequate $(34,35)$, our population showed a higher dietary intake of vitamin $\mathrm{D}(\sim 170 \mathrm{IU} /$ day $)$ and calcium $(\sim 800 \mathrm{mg} /$ day $)$. It is possible to credit this difference to the fact that our population is composed of osteoporotic patients who most likely received nutritional guidance to consume these nutrients.

In our public outpatient clinic, $25(\mathrm{OH}) \mathrm{D}$ blood test is not routinely available, and the prescription of cholecalciferol may vary based on the clinical assessment of the patient. However, most commonly, we adopt standardized weekly doses of 7,000 IU or 14,000 IU $(1,35)$. It is important to remember that the mean cholecalciferol dose was 13,185 IU/week for the participants who received vitamin D supplementation and had adequate vitamin D status. The decision tree showed that the $29 \mathrm{pa}-$ tients who were receiving a cholecalciferol dose $>14,000$ IU/week achieved a mean $25(\mathrm{OH}) \mathrm{D}$ concentration $>$ $30 \mathrm{ng} / \mathrm{mL}$, which is considered a desirable $25(\mathrm{OH}) \mathrm{D}$ concentration in terms of PTH levels and health outcomes by most experts $(8,36)$. These findings corroborate the observations of other authors $(11,35,37-39)$ and indicate that even in a sunny country such as Brazil, higher supplemental vitamin $\mathrm{D}$ doses may be necessary to guarantee adequate vitamin D status (11).
As shown by others $(6,32,33,38)$, the $25(\mathrm{OH}) \mathrm{D}$ concentration was positively correlated with BMD and negatively correlated with PTH in our research. This positive effect on BMD (FN) could be a consequence of a decrease in the PTH concentrations of the patients with higher levels of $25(\mathrm{OH}) \mathrm{D}(6)$. Because secondary hyperparathyroidism stimulates bone loss and increases the risk of fractures (6), these observations may be clinically relevant, particularly for patients in treatment for osteoporosis.

The majority of subjects were evaluated during the winter, which might have contributed to the lack of a relationship between the $25(\mathrm{OH}) \mathrm{D}$ concentration and the sun exposure index, which has also been observed by other authors (40). We can also speculate that the lack of a relationship between sun exposure index and $25(\mathrm{OH}) \mathrm{D}$ may be explained by the fact that our population, which has relative homogeneity, lives in a region where air quality exceeds the standards for several days out of the year, and air pollution can adversely affect vitamin $\mathrm{D}$ production in the skin $(5,30,41)$.

We found that higher $25(\mathrm{OH}) \mathrm{D}$ concentrations were associated with various parameters, including not-smoking, physical activity, the month of the blood draw and the use of cholecalciferol. However, in the multivariate analysis, only the supplemental dose of vitamin $\mathrm{D}$, physical activity and the month of the blood draw remained associated with higher $25(\mathrm{OH}) \mathrm{D}$ concentrations. Other authors have also observed lower $25(\mathrm{OH}) \mathrm{D}$ concentrations in smokers $(10,42)$. Although a negative correlation between the $25(\mathrm{OH}) \mathrm{D}$ concentration and obesity has been observed by various authors $(5,8,43)$, this result was not produced in our study and others (44). The majority of the participants had BMI between 18.5 and $29.9 \mathrm{~kg} / \mathrm{m}^{2}$ (median 25.6 $\mathrm{kg} / \mathrm{m}^{2}$ ), whereas only $13.5 \%$ had BMI $\geq 30 \mathrm{~kg} / \mathrm{m}^{2}$. In our study, this relative homogeneity of the population and the small number of participants with extreme weight values $\left(\mathrm{BMI}<18.5 \mathrm{~kg} / \mathrm{m}^{2}\right.$ and $\geq 30 \mathrm{~kg} / \mathrm{m}^{2}$ ) might have contributed to the lack of a relationship between the $25(\mathrm{OH}) \mathrm{D}$ concentration and obesity $(44)$.

The engagement in physical activity increased the odds of having adequate vitamin D status 2.12 times. This association does not necessarily indicate causality, but physical activity has been associated with higher levels of $25(\mathrm{OH}) \mathrm{D}$ in various studies $(9,10,45,46)$. One could bear in mind that higher levels of serum $25(\mathrm{OH})$ D may promote a sense of well-being and increase one's willingness to engage in physical activity. On the other 
hand, people who exercise tend to be outside more frequently and are more active, which leads to greater sun exposure. Interestingly, in our study, no relationship between sun exposure index and $25(\mathrm{OH}) \mathrm{D}$ was observed. We certainly do not intend to question the importance of sun exposure in the production of vitamin $\mathrm{D}$, given that our results showed that the season had an influence on serum $25(\mathrm{OH}) \mathrm{D}$ concentration. As expected, the serum 25 $(\mathrm{OH}) \mathrm{D}$ concentrations were lower in August (the end of winter), and the patients' blood tests in September (the beginning of spring) were more likely to show an adequate serum $25(\mathrm{OH}) \mathrm{D}$ concentration $(\mathrm{OR}=2.52)$. However, our results indicated that physical activity was a factor associated with improved vitamin D status even after controlling for the month of the blood draw (in the logistic regression analysis). Thus, we could hypothesize that exercise independently modifies $25(\mathrm{OH}) \mathrm{D}$ levels (46). Cholecalciferol is fat-soluble and stored in body fat depots. As physical activity promotes weight loss, the stored cholecalciferol may be released, which leads to an increased 25(OH)D concentration (44). Exercise increases energy expenditure and activates thermogenic function in adipose tissues. Recently, in animal studies, irisin was described; this hormone, which is secreted by muscle, has powerful effects on the browning of white adipose tissues and activates thermogenic function in adipose tissue (47). Perhaps these effects promote a decrease in the uptake of vitamin D by adipose tissue (reducing adipose stores), enhancing the circulating vitamin D levels. Another hypothesis is that an increase in serum 25(OH) $\mathrm{D}$ may be linked with increased muscle usage and the release of $25(\mathrm{OH}) \mathrm{D}$ from the muscle tissue itself. More recently, in animal studies, it was shown that after uptake into mature muscle cells, $25(\mathrm{OH}) \mathrm{D}$ is held there by vitamin $\mathrm{D}$ binding protein. This sequestration by the skeletal muscle could protect $25(\mathrm{OH}) \mathrm{D}$ from hepatic degradation and thus could provide a functional store to maintain vitamin D status (48). However, more data are needed to clarify these complex relationships.

\section{CONCLUSIONS}

In this osteoporotic population, the prevalence of inadequate vitamin D status was high (73.3\%). We found that vitamin D supplementation of 7,000 IU/week was not enough to reach the desired $25(\mathrm{OH}) \mathrm{D}$ concentration $(\geq 30 \mathrm{ng} / \mathrm{mL})$, and our findings suggest that doses $\geq 14,000 \mathrm{IU} /$ week seem optimal. These findings reinforce the need for laboratory assessments of $25(\mathrm{OH}) \mathrm{D}$ concentration, even in sunny countries such as Brazil, at least for higher-risk patients such as osteoporotic patients. Lower serum $25(\mathrm{OH}) \mathrm{D}$ concentrations were found at the end of the winter (August), and engaging in physical exercise could be a factor in improving vitamin $\mathrm{D}$ status. These observations may be useful for planning public health strategies for improving vitamin $\mathrm{D}$ status in the general population.

Acknowledgments: this research was sponsored by the São Paulo Research Foundation (Fapesp); Grant 08/55567-7. Marília Brasilio Rodrigues Camargo received a scholarship from the National Council for Scientific and Technological Development (CNPq). Roche Diagnostics of Brazil kindly provided PTH, CTX-I and PINP assay kits.

Disclosure: no potential conflict of interest relevant to this article was reported.

\section{REFERENCES}

1. Bishoff-Ferrari HA. How to select the doses of vitamin $D$ in the management of osteoporosis. Osteoporos Int. 2007;18:401-7.

2. Holick MF, ChenTC. Vitamin D deficiency: a worldwide problem with health consequences. Am J Clin Nutr. 2008;87(suppl):1080S-6S.

3. Holick MF. The vitamin D epidemic and its health consequences. J Nutr. 2005;135:2739S-48S.

4. Bischoff-Ferrari H, Willet WC, Wong JB, Stuck AE, Staehelin HB, Orav EJ, et al. Prevention of nonvertebral fractures with oral vitamin D and dose dependency. Arch Intern Med. 2009;169(6):551-61.

5. Unger MD, Cuppari L, Titan SM, Magalhães MCT, Sassaki AL, Reis LM, et al. Vitamin D status in a sunny country: where has the sun gone? Clin Nutr. 2010;29(6):784-8.

6. Lips P. Vitamin D deficiency and secondary hyperparathyroidism in the elderly: consequences for bone loss and fractures and therapeutic implications. Endocr Rev. 2001;22(4):477-501.

7. Rizzoli R, Eisman JA, Norquist J, Ljunggren O, Krishnarajah G, Lim SK, et al. Risk factors for vitamin D inadequacy among women with osteoporosis: an international epidemiological study. Int J Clin Pract. 2006;60(8):1013-19.

8. Holick MF, Siris ES, Binkley N, Beard MK, Khan A, Katzer JT, et al. Prevalence of vitamin $D$ inadequacy among postmenopausal North American receiving osteoporosis therapy. J Clin Endocrinol Metab. 2005;90(6):3215-24.

9. Maeda SS, Kunii IS, Hayashi LF, Lazaretti-Castro M. Increases in summer serum 25-hydroxyvitamin D (25(OH)D) concentrations in elderly subjects in São Paulo, Brazil vary with age, gender and ethnicity. BMC Endocr Disord. 2010;10:12.

10. Nanri A, Foo LH, Nakamura K, Hori A, Poudel-Tandukar K, Matsushita $Y$, et al. Serum 25-hydroxyvitamin D concentrations and season-specific correlates in Japanese adults. J Epidemiol. $2011 ; 21(5): 346-53$.

11. Pignotti GAP, Genaro PS, Pinheiro MM, Szejnfeld VL, Martini LA. Is a lower dose of vitamin $D$ supplementation enough to increase 25(OH)D status in a sunny country? Eur J Nutr. 2010;49:277-83. 
12. Mithal $A$, Wahl DA, Bonjour JP, Burckhardt $P$, Dawson-Hughes $B$, Eisman JA, et al.; IOF Committee of Scientific Advisors (CSA) Nutrition Working Group. Global vitamin D status and determinants of hypovitaminosis D. Osteoporos Int. 2009;20(11):1807-20.

13. Lips P, Hosking D, Lippuner K, Norquist JM, Wehren L, Maalouf G, et al. The prevalence of vitamin $D$ inadequacy amongst women with osteoporosis: an international epidemiological investigation. J Int Med. 2006;260(3):245-54.

14. Brandão CMA, Camargos BM, Zerbini CA, Papler PG, Mendonça LMC, Albergaria B-H, et al. 2008 Offical positions of the Brazilian Society of Clinical Densitometry - SBDens. Arq Bras Endocrinol Metab. 2009;53(1):107-12.

15. Ferraz MB, Oliveira LM, Araújo PM, Atra E, Tugwell P. Crosscultural reliability of the physical ability dimension of health assessment questionnaire. J Rheumatol. 1990;17(6):813-17.

16. Portale AA. Blood calcium, phosphorus, and magnesium. In: Favus MJ (ed). Primer on the metabolic bone diseases and disorders of mineral metabolism. 4th ed. Philadelphia: Lippincott Williams \& Wilkins; 1999. p. 115-8.

17. World Health Organization (2000) Obesity: preventing and managing the global epidemic. Available at: http://www.who.int/nutrition/ publications/obesity/WHO_TRS_894/en/. Accessed on: Oct 10, 2012.

18. Fitzpatrick TB. The validity and practicality of sun-reactive skin types I through VI. Arch Dermatol. 1988;124(6):869-71.

19. Saraiva GL, Cendoroglo MS, Ramos LR, Araújo LMQ, Vieira JGH, Kunii I, et al. Influence of ultraviolet radiation on the production of 25 hydroxyvitamin $D$ in the elderly population in the city of São Paulo (2334'S), Brazil. Osteoporos Int. 2005;16:1649-54.

20. Bruce B, Fries JF.The Stanford Health Assessment Questionnaire: dimensions and practical applications. Health Qual Life Outcomes. 2003;1(1):20.

21. Moreira-Pfrimer LDF, Pedrosa MAC, Teixeira L, Lazaretti-Casto M. Treatment of vitamin D deficiency increases lower limb muscle strength in institutionalized older people independently of regular physical activity: a randomized double-blind controlled Trial. Ann Nutr Metab. 2009;54:291-300.

22. CDC/NCHS (2006) National Health and Nutrition Examination Survey: body composition procedures manual. Available at: http://www.cdc.gov.nchs/data/nhanes_05_06/BC.pdf. Accessed on: Aug 31, 2012.

23. HangartnerTN, Warner S, Braillon P, Jankowski L, Shepherd J.The official positions of the international society for clinical densitometry: acquisition of dual-energy X-ray absorptiometry body composition and considerations regarding analysis and repeatability of measures. J Clin Densitom. 2013;16(4):520-36.

24. Tothill P. Dual-energy X-ray absorptiometry measurements of total-body bone mineral during weight change. J Clin Densitom. 2005;8(1):31-8.

25. Instituto Brasileiro de Geografia e Estatística (2010). Síntese de indicadores sociais. Uma análise das condições de vida da população brasileira. Available at: http:/ibge.gov.br/home/estatísticas/ população/condicaodevida/ indicadoresminimos/sinteseindicsociais2010/SIS_2010.pdf. Accessed on: Oct 10, 2012.

26. Instituto Brasileiro de Geografia e Estatística (2010). Antropometria e estado nutricional de crianças, adolescentes e adultos no Brasil. Available at: http://ibge.gov.br/home/estatísticas/população/condicaodevida/pof/2008_2009_encaa/pof_20082009_encaa. pdf. Accessed on: Oct 10, 2012.

27. Schmidt MI, Duncan BB, Azevedo e Silva G, Menezes AM, Monteiro CA, Barreto SM, et al. Chronic non-communicable diseases in Brazil: burden and current challenges. Lancet. 2011; 377:1949-61.

28. Paim J, Travassos C, Almeida C, Bahia L, Macinko J. The Brazilian health system: history, advances and challenges. Lancet. 2011;377:1778-97.
29. Schmidt MI, Duncan BB, Hoffmann JF, Moura L, Malta DC, Carvalho RMS. Prevalence of diabetes and hypertension based on self-reported morbidity survey, Brazil, 2006. Rev Saude Publica. 2009;43 Suppl 2:74-82

30. Orlando JP, Alvim DS, Yamazaki A, Correa SM, Gatti LV. Ozone precursors for the São Paulo metropolitan area. SciTotal Environ. 2010;408(7):1612-20.

31. Saraiva GL, Cendoroglo MS, Ramos LR, Araújo LMQ, Vieira JGH, Maeda SS, et al. Prevalence of vitamin D deficiency, insufficiency and secondary hyperparathyroidism in the elderly inpatients and living in the community of the city of São Paulo, Brazil. Arq Bras Endocrinol Metab. 2007;51(3):437-42.

32. Scalco R, Preamor MO, Fröehlich, FurlanettoTW. High prevalence of hypovitaminosis and secondary hyperparathyroidism in elders living in nonprofit homes in South Brazil. Endocrine. 2008;33:95-100.

33. Bandeira F, Griz L, Freese E, Lima DC, Thé AC, Diniz ET, et al. Vita$\min \mathrm{D}$ deficiency and its relationship with bone mineral density among postmenopausal women living in the tropics. Arq Bras Endocrinol Metab. 2010;54(2):227-32.

34. Pinheiro MM, Schuch NJ, Genaro PS, Ciconelli RM, Ferraz MB, Martini LA. Nutrient intakes related to osteoporotic fractures in men and women - The Brazilian Osteoporosis Study (BRAZOS). Nutr J. 2009;8:6.

35. Heaney RP. The vitamin D requirement in health and disease. $J$ Steroid Biochem Mol Biol. 2005;97(1-2):13-9.

36. Maeda SS, Saraiva GL, Kunii IS, Hayashi LF, Cendoroglo MS, Ramos $L R$, et al. Factors affecting vitamin $D$ status in different populations in the city of São Paulo, Brazil: the São PAulo vitamin D Evaluation Study (SPADES). BMC Endocr Disord. 2013;13:14.

37. Heaney RP, Davies KM, Chen TC, Holick MF, Barger-Lux MJ. Human serum 25-hydroxycholecalciferol response to extended oral dosing with cholecalciferol. Am J Clin Nutr. 2003;77:204-10.

38. Fuleihan GE-H, Nabulsi M, Tamin H, Maalouf J, Salamoun M, Khalife $\mathrm{H}$, et al. Effect of vitamin $\mathrm{D}$ replacement on musculoskeletal parameters in school children: a randomized controlled trial. J Clin Endocrinol Metab. 2006;91(2):405-12.

39. Holick MF, Biancuzzo RM, Chen TC, Klein EK, Young A, Bibuld D, et al. Vitamin D2 is as effective as Vitamin D3 in maintaining circulating concentrations of 25-hydroxyvitamin D. J Clin Endocrinol Metab. 2008;93(3):677-81.

40. Hanwell HEC, Vieth R, Cole DEC, Scillitani, Modoni S, Frusciante $\mathrm{V}$, et al. Sun exposure questionnaire predicts circulating 25-hydroxyvitamin D concentrations in Caucasian hospital workers in southern Italy. J Steroid Biochem Mol Biol. 2010;121:334-7.

41. Manicourt D-H, Devogelaer J-P. Urban tropospheric ozone increases the prevalence of vitamin $D$ deficiency among Belgian postmenopausal women with outdoor activities during summer. J Clin Endocrinol Metab. 2008;93(10):3893-9.

42. Brot $\mathrm{C}$, Jorgensen NR, Sorensen $\mathrm{OH}$. The influence of smoking on vitamin $\mathrm{D}$ status and calcium metabolism. Eur $\mathrm{J}$ Clin Nutr. 1999;53(12):920-6.

43. Mason C, Xiao L, Imayama I, Duggan CR, Bain C, Foster-Schubert $\mathrm{KE}$, et al. Effects of weight loss on serum vitamin $\mathrm{D}$ in postmenopausal women. Am J Clin Nutr. 2011;94:95-103.

44. Canto-Costa MHS, Kunii I, Hauache OM. Body fat and cholecalciferol supplementation in elderly homebound individuals. Braz $\mathrm{J}$ Med Biol Res. 2006;39(1):91-8.

45. Scragg R, Camargo CAJ. Frequency of leisure-time physical activity and serum 25-hydroxyvitamin D levels in the US population: results from the Third National Health and Nutrition Examination Survey. Am J Epidemiol. 2008;168:577-86.

46. Brock K, Huang W-H, Fraser DR, Ke L, Tseng M, Stolzenberg-Solomon $\mathrm{R}$, et al. Low vitamin $\mathrm{D}$ status is associated with physical 
inactivity, obesity and low vitamin $D$ intake in a large US sample of healthy middle-aged men and women. J Steroid Biochem Mol Biol. 2010;121:462-6.

47. Boström P, Wu J, Jedrychowski MP, Korde A, Ye L, Lo JC, et al. A $P G C 1-\alpha$-dependent myokine that drives brown-fat-like development of white fat and thermogenesis. Nature. 2012;481:463-8.
48. Abboud M, Puglisi DA, Davies BN, Rybchyn M, Whitehead NP, Brock KE, et al. Evidence for specific uptake and retention mechanism for 25-hydroxyvitamin D (25OHD) in skeletal muscle cells. Endocrinology. Endocrinology. 2013;154(9):3022-30. 